\title{
Intermediate snail hosts of French Fasciola hepatica: Lymnaea neotropica and Lymnaea viatrix are better hosts than local Galba truncatula
}

\author{
R. Sanabria $\cdot$ R. Mouzet $\cdot$ B. Courtioux $\cdot$ P. Vignoles \\ D. Rondelaud • G. Dreyfuss • J. Cabaret • J. Romero
}

Received: 22 May 2012 / Accepted: 13 July 2012 /Published online: 4 August 2012

(C) Springer-Verlag 2012

\begin{abstract}
Allopatric and sympatric infections of Lymnaea neotropica and Lymnaea viatrix var. ventricosa with Argentinean and French isolates of Fasciola hepatica were carried out to determine the capacity of these snails to produce metacercariae and to verify if this capacity changed with snail generation. The same process was also made with a French population of Galba truncatula known to be highly susceptible to French isolates of the parasite. In each lymnaeid species separately considered, the survival rate at day 30 postexposure and prevalence of $F$. hepatica infection in the group infected with Argentinean miracidia were significantly greater than those recorded in the corresponding French one. Compared to infected G. truncatula, both South American lymnaeids had longer patent periods and produced a higher number of metacercariae. The highest infections were noted with $L$. v. ventricosa. In the three snail species, metacercarial production was more important with the Argentinean isolate of miracidia than with the French one. If three successive generations of $L$. v. ventricosa are exposed to the same French
\end{abstract}

\section{R. Sanabria $\cdot$ J. Romero}

CEDIVE, Fac. Cs. Veterinarias, Universidad Nacional de La Plata, Alvear 803, (7130),

Chascomús, Buenos Aires, Argentina

R. Mouzet $\cdot$ B. Courtioux $\cdot$ P. Vignoles $\cdot$ D. Rondelaud $\cdot$

G. Dreyfuss $(\square)$

INSERM U 1094, Faculties of Medicine and Pharmacy, 87025 Limoges, France

e-mail: gilles.dreyfuss@unilim.fr

J. Cabaret

UMR 1282 Infectiology and Public Health, INRA,

37380 Nouzilly, France

J. Cabaret

UMR 1282 University of Tours,

37000 Tours, France isolate of miracidia, cercarial production significantly increased from parents to the F2 generation, while the other characteristics of infection only showed insignificant variations. L. neotropica and L. v. ventricosa are better intermediate hosts for French F. hepatica than local G. truncatula. The numerical increase of shed cercariae in the F1 and F2 generations of $L$. v. ventricosa demonstrates a rapid adaptation of this species to the French isolate of the parasite.

\section{Introduction}

According to the theory of local adaptation in parasite systems, a digenean should perform better on its local (sympatric) snail hosts than on foreign (allopatric) hosts and thus would become adapted to these local hosts (Lively and Dybdahl 2000; Greischar and Koskella 2007; King et al. 2011). The efficiency of such sympatric combinations has been shown in several snail-parasite systems (Muñoz-Antoli et al. 2010; Mostafa and el-Dafrawy 2011). However, this theory was not verified in other snail-parasite systems (Prugnolle et al. 2006; Osnas and Lively 2011). This variable nature of results was also found in the Galba truncatula-Fasciola hepatica system. Local adaptation between both partners was verified in the field (Abrous et al. 1999, 2000) and even during the larval development of $F$. hepatica within its snail host (Belfaiza et al. 2005). However, the better fitness noted in these sympatric infections cannot be generalised because allopatric combinations of $G$. truncatula and $F$. hepatica are sometimes more efficient for cercarial production than sympatric ones. Spanish isolates of $F$. hepatica miracidia, coming from cattle infections, were more infective to French populations of $G$. truncatula than miracidial isolates originating from central France (Gasnier et al. 2000). A higher prevalence of $F$. hepatica infection and a greater cercarial production were also noted in allopatric combinations of 
French snails and Moroccan miracidia (Goumghar et al. 2001). In the report by Coelho et al. (2009), the results were more conflicting. Allopatric combinations between Lymnaea columella and $F$. hepatica miracidia were more efficient than sympatric ones when snails living in south-western Brazil (Itajubá) were used, but the opposite was observed in allopatric infections with snails from south-eastern Brazil and also in both types of sympatric infections. According to Coelho et al. (2009), the host-parasite relationships may vary with the geographical origin of snails and that of flukes involved.

In view of these findings, one may wonder if the better results noted by Gasnier et al. (2000) and Goumghar et al. (2001) during allopatric infections of French snails with Spanish and Moroccan isolates of F. hepatica be found when lymnaeid species other than $G$. truncatula are used for experimental infections. To answer this question, it was necessary to select lymnaeids known to sustain larval development of $F$. hepatica and to use the experimental protocol already applied by the above-mentioned authors because the characteristics of snails and parasites and also the experimental protocol used by biologists were important for detecting local adaptation in coevolving species interactions (Hoeksema and Forde 2008). For this reason, we have chosen two populations of South American lymnaeids: Lymnaea neotropica and $L$. viatrix var. ventricosa, which are currently raised under laboratory conditions at CEDIVE (Faculty of Veterinary Sciences, National University of La Plata, Buenos Aires, Argentina). Both species belong to the Galba group (amphibious snails) and can be identified by the relative length of their penis sheath and preputium (Pointier et al. 2006) and molecular biology (Bargues et al. 2007). Their biological differences are still misunderstood because these snail species were confused under the name of Lymnaea viatrix before the 2000s and were only separated from each other since 2007 (Bargues et al. 2007). Allopatric and sympatric infections of these snail populations with Argentinean and French isolates of $F$. hepatica were thus carried out to compare their potential for metacercarial production and to verify if this capacity can be noted in further generations of these snails when the method by Rondelaud et al. (2007) for the breeding of lymnaeids was used. Controls were constituted by a French population of G. truncatula, infected and raised according to the same protocol.

\section{Materials and methods}

Snails and F. hepatica isolates

The two South American lymnaeids were raised in CEDIVE since 2008 (L. neotropica) and 1996 (L. v. ventricosa). The first species came from a population living in San Pedro, Buenos Aires, Argentina ( $\left.33^{\circ} 40^{\prime} \mathrm{S}, 59^{\circ} 39^{\prime} \mathrm{W}\right)$, while $L$. v. ventricosa originated from Paysandú, Uruguay $\left(36^{\circ} 00^{\prime} \mathrm{S}\right.$, $57^{\circ} 30^{\prime} \mathrm{W}$ ). As the systematics of South American lymnaeids is controversial and cannot be made with the single use of morphological criteria (Duffy et al. 2009; Mera y Sierra et al. 2009), the identification of these two species was performed using PCR-RFLP and sequencing of ITS-1 of their nuclear rDNA (Sanabria et al. 2012). A French population of $G$. truncatula was used as controls and was living in a road ditch at Chézeau Chrétien, commune of Chitray, department of Indre, central France ( $46^{\circ} 40^{\prime} 27^{\prime \prime}$ $\left.\mathrm{N}, 1^{\circ} 21^{\prime} 21^{\prime \prime} \mathrm{E}\right)$. This last population was known to be highly susceptible ( $>60 \%$ ) to French miracidia of F. hepatica (Dreyfuss et al. 2007). Four-millimetre-high snails (Table 1) were collected from each population. Eggs of the Argentinean isolate of $F$. hepatica were collected in the gall bladders of cattle from Buenos Aires, while those of the French isolate came from the gall bladders of cattle at the slaughterhouse of Limoges (France). All the eggs were washed several times with spring water and were incubated for 12 days at $24{ }^{\circ} \mathrm{C}$ in the dark (Ollerenshaw 1971).
Table 1 Main characteristics of snail populations and miracidial isolates used in the two experiments

\begin{tabular}{lllc}
\hline Experiment (purpose) & $\begin{array}{l}\text { Snail population } \\
\text { (origin) }\end{array}$ & $\begin{array}{l}\text { Origin of } \\
\text { F. hepatica }\end{array}$ & $\begin{array}{l}\text { Total number } \\
\text { of preadult snails } \\
\text { at exposure }\end{array}$ \\
\hline $\begin{array}{l}\text { A (aptitude of each snail population } \\
\text { as an intermediate host of } F \text {. hepatica) }\end{array}$ & L. neotropica (Argentina) & $\begin{array}{l}\text { Argentina } \\
\text { France }\end{array}$ & 100 \\
& L. v. ventricosa (Uruguay) & Argentina & 100 \\
& & France & 100 \\
& G. truncatula (France) & Argentina & 100 \\
B (development of $F$. hepatica infection & Parents & France & 100 \\
in $L . v$ ventricos from parents to the & F1 & France & 50 \\
F2 generation) & F2 & & 50 \\
& & & 50 \\
\hline
\end{tabular}


Experimental infections of snails

Table 1 gives the purpose of each experiment, the snail strain, the origin of $F$. hepatica miracidia and the total number of preadult snails (shell height, $4 \mathrm{~mm}$ ) in each snail group. In experiment (A), the three populations of snails were subjected to Argentinean or French miracidia of $F$. hepatica. In contrast, only L. v. ventricosa was used in experiment (B) because these snails were the most efficient for cercarial production with the French isolate of $F$. hepatica miracidia. The F1 snails originated from eggs laid by their infected parents between weeks 2 and 5 post-exposure (p.e.). A similar protocol was used for the F2 generation. This protocol for the F1 and F2 generations was chosen in order that these descendants have a first contact with the parasite through their infected parents.

A bimiracidial exposure was performed for each snail. The lymnaeids were then raised per groups of ten individuals in 14-cm Petri dishes for 30 days according to the method by Rondelaud et al. (2007). Food constituted of dried leaves of lettuce and dead leaves of grass (Molinia caerulea), while several stems of spring moss (Fontinalis sp.) ensured oxygenation of the water layer (concentration of dissolved calcium in spring water, $35 \mathrm{mg} / \mathrm{l})$. Water and food, if necessary, were changed every day. The Petri dishes were placed in an air-conditioned room under the following conditions: a constant temperature of $20^{\circ} \mathrm{C}\left( \pm 1^{\circ} \mathrm{C}\right)$, natural photoperiod of 10-h light. At day 30 p.e., each surviving snail was individually placed in a $35-\mathrm{mm}$ Petri dish with pieces of dead grass, lettuce and spring moss. These last recipients were also kept at $20^{\circ} \mathrm{C}$. A daily surveillance was performed to change water and food, if necessary. If metacercariae were present, they were counted and removed from the Petri dish. This surveillance was applied up to the death of each snail.

\section{Parameters studied}

The first two parameters were snail survival at day 30 p.e. and the prevalence of $F$. hepatica infection (calculated in relation to the number of surviving snails at day 30 p.e.). For each population, the difference between the values recorded in the Argentinean and the French groups was analysed using a $\chi^{2}$ test. The growth of cercariae-shedding (CS) snails during the experiment, the length of the prepatent period, the length of the patent period and the total number of metacercariae were also taken into account. Individual values recorded for these last five parameters were averaged, and their standard deviations were calculated, taking into account snail groups. One-, two- or three-way analysis of variance was used to establish levels of significance. All the statistical analyses were made using the Statview 5.0 software.

\section{Results}

Lymnaeid species and snail infection

Compared to French G. truncatula infected with Argentinean miracidia (Table 2), snail survival at day 30 p.e. was significantly higher $\left(\chi^{2}=7.29, P<0.05\right)$ in both South American species. In contrast, in groups with French miracidia, survival was significantly lower $\left(\chi^{2}=12.15, P<0.01\right)$ for $L$. v. ventri$\cos a$ than for the other two lymnaeids. In each species separately considered, the survival rate in the group infected with Argentinean miracidia was significantly greater $(G$. truncatula, $\chi^{2}=5.21, P<0.05 ;$ L. neotropica, $\chi^{2}=37.7, P<0.001 ; L$. v. ventricosa, $\left.\chi^{2}=11.07, P<0.001\right)$. The prevalence of $F$. hepatica infection in the three lymnaeids did not significantly differ from each other, whatever the origin of miracidia; whereas that noted in the Argentinean group of each snail species was significantly greater $\left(G\right.$. truncatula, $\chi^{2}=23.73$, $P<0.001$; L. neotropica, $\chi^{2}=30.6, P<0.001 ; L$. v. ventricosa, $\left.\chi^{2}=14.66, P<0.001\right)$ than that recorded in the corresponding French one. The growth of CS L. neotropica and L. v. ventricosa during the experiment was significantly $(F=87.19, P<$ $0.001)$ greater than that of $G$. truncatula, whereas the miracidial origin had no clear effect on this parameter.

The lengths of prepatent periods (Table 3) ranged in the same scale of values, and no significant difference was

Table 2 Survival of exposed snails at day 30 post-exposure, prevalence of infection and growth of CS snails in the three species of lymnaeids infected with Argentinean or French miracidia (experiment A)

\begin{tabular}{llccc}
\hline Snail population & Origin of F. hepatica & $\begin{array}{l}\text { Number of surviving snails } \\
\text { at day 30 p.e. (\%) }\end{array}$ & $\begin{array}{l}\text { Number of CS snails } \\
\text { (prevalence in \%) }\end{array}$ & $\begin{array}{l}\text { Mean growth (SD) of CS snails } \\
\text { during the experiment (mm) }\end{array}$ \\
\hline G. truncatula & Argentina & $76(76.0)$ & $23(30.2)$ & $2.0(0.2)$ \\
& France & $61(61.0)$ & $44(72.1)$ & $2.0(0.1)$ \\
L. neotropica & Argentina & $89(89.0)$ & $18(20.6)$ & $2.8(0.4)$ \\
& France & $70(70.0)$ & $32(69.5)$ & $2.8(0.4)$ \\
L. v. ventricosa & Argentina & $87(87.0)$ & $29(32.5)$ & $3.1(0.3)$ \\
& France & $46(46.0)$ & $44(62.8)$ & $2.9(0.4)$ \\
\hline
\end{tabular}


Table 3 Prepatent period, patent period and total number of metacercariae noted in the three species of lymnaeids infected with Argentinean or French miracidia (experiment A)

\begin{tabular}{|c|c|c|c|c|c|}
\hline \multirow[t]{2}{*}{ Snail population } & \multirow[t]{2}{*}{ Origin of $F$. hepatica } & \multicolumn{2}{|c|}{ Mean length (SD) in days } & \multicolumn{2}{|c|}{ Mean number (SD) of metacercariae } \\
\hline & & Prepatent period & Patent period & Per CS snail & Per snail exposed to miracidia \\
\hline \multirow[t]{2}{*}{ G. truncatula } & Argentina & $38.4(1.7)$ & $85.9(22.4)$ & $897.3(229.9)$ & 206.3 \\
\hline & France & $39.3(2.0)$ & $18.2(8.2)$ & $222.1(93.1)$ & 97.7 \\
\hline \multirow[t]{2}{*}{ L. neotropica } & Argentina & $42.9(2.9)$ & $65.0(33.2)$ & $670.1(375.9)$ & 120.6 \\
\hline & France & $43.0(3.0)$ & $51.1(17.9)$ & $404.6(224.4)$ & 129.4 \\
\hline \multirow[t]{2}{*}{ L. v. ventricosa } & Argentina & $42.3(1.5)$ & $96.3(34.6)$ & $1383.0(698.6)$ & 401.0 \\
\hline & France & $42.0(1.9)$ & $54.0(27.5)$ & $542.3(420.4)$ & 238.6 \\
\hline
\end{tabular}

CS cercariae-shedding snail

noted. In the case of patent periods, higher values were found in the three Argentinean groups, thus indicating the significant effect of miracidial origin $(F=30.37, P<0.001)$. The shell growth of CS snails had also a significant influence $(F=$ 137.62, $P<0.001)$, whereas that of lymnaeid species was insignificant. Similar findings were also noted for metacercariae, with higher numbers in the Argentinean groups. The highest values were noted for $L$. v. ventricosa, with a mean of 1,383 metacercariae in the Argentinean group and 542 in the French one. Significant effects were noted for lymnaeid species $(F=15.04, P<0.001)$, the origin of miracidia $(F=26.51$, $P<0.001)$ and snail growth $(F=134.44, P<0.001)$.

If the metacercarial production of each group is related to the number of snails at miracidial exposure (Table 3), the highest difference between the values of allopatric and sympatric groups was noted for $L$. v. ventricosa, while the numbers for $L$. neotropica were close to each other.

Generation of $L$. v. ventricosa and snail infection with French miracidia

Table 4 gives the values of the six parameters. Even if there was a slight increase in the survival rates at day 30 p.e. from parents to the F2 generation, this variation was insignificant. Similar findings were also noted for the prevalence of $F$. hepatica infections, the shell growth of CS snails during experiment, the length of the prepatent period and that of the patent period. In contrast, the number of metacercariae significantly increased in time, going from a mean of 364.7 cercariae in parents to 565.1 in the F2 group.

\section{Discussion}

Among the three lymnaeid species experienced in the present study, $L$. v. ventricosa was the most productive with a mean of 1,383 metacercariae in the Argentinean group and 542 in the French one. Moreover, these cercariae were shed during a long patent period of 96.3 and 54.0 days, respectively. Such values were never obtained with French populations of $G$. truncatula when they were experimentally infected with sympatric isolates of $F$. hepatica miracidia (Rondelaud et al. 2004, 2007). The differences noted between values of these two parameters can be partly explained by the report of Mas-Coma et al. (2001). When two populations of Lymnaea sp. (unidentified species), coming from Northern Altiplano (Bolivia), were infected with sympatric miracidia of $F$. hepatica, the authors noted a longer cercarial shedding period (up to 85 days at $20{ }^{\circ} \mathrm{C}$ ) and a higher cercarial production (up to 589 metacercariae). According to Mas-Coma et al. (2001), these findings may be interpreted as the consequence of strategies associated with adaptation to high altitude conditions. Even if South American lymnaeids would be better intermediate hosts for local
Table 4 Main characteristics of $F$. hepatica infection in three groups of $L$. v. ventricosa according to snail generation (experiment B)

CS cercariae-shedding snails $* P<0.05$ (Anova, $F=6.62$ )

\begin{tabular}{llll}
\hline Parameters & Parents & F1 & F2 \\
\hline Number of surviving snails at day 30 p.e. (\%) & $34(68.0)$ & $35(70.0)$ & $38(76.0)$ \\
Number of CS snails (prevalence \%) & $22(64.7)$ & $25(71.4)$ & $31(81.5)$ \\
Mean growth (SD) of CS snails during the experiment (mm) & $2.7(0.3)$ & $2.7(0.3)$ & $2.8(0.3)$ \\
Mean length (SD) of the prepatent period (days) & $41.9(2.1)$ & $42.0(1.7)$ & $42.1(2.0)$ \\
Mean length (SD) of the patent period (days) & $48.0(17.3)$ & $57.8(24.9)$ & $59.6(28.6)$ \\
Mean number (SD) of metacercariae & $364.7(192.4)$ & $462.3(201.1)$ & $565.1(313.4)^{*}$ \\
\hline
\end{tabular}


F. hepatica, this first interpretation did not explain all findings noted in the present study, and another complementary explanation must be proposed. In our opinion, the values recorded for the length of patent period and metacercarial production between Argentinean and French groups of snails, whatever lymnaeid species, demonstrated that the Argentinean isolate of $F$. hepatica used in this experiment seemed little aggressive contrary to the French isolate of the parasite. This last result might be the consequence of anthelmintics used by farmers to treat infected cattle (according to Reynal (2001), most farmers in central France used triclabendazole to treat cattle against fasciolosis) and increased infectivity of local miracidia towards populations of $G$. truncatula (Dreyfuss et al. 2007).

Even when the numerical variations noted for five parameters in parent $L . v$ ventricosa and their descendants were insignificant, snail survival, prevalence of infection, the patent period and the number of metacercariae showed slight increases from parents to the F2 generation. These results suggested a rapid adaptation of $L$. v. ventricosa to the French isolate of the parasite. Similar adaptations of lymnaeids to an unusual isolate of $F$. hepatica over several generations of the snail were already reported for other snail-parasite systems such as the Lymnaea peregra-F. hepatica model (Boray 1966, 1969) or that concerning Omphiscola glabra and Paramphistomum daubneyi in central France (Dreyfuss et al. 2010), for example. This finding demonstrates the capacity of the South American L. v. ventricosa as an intermediate host for another isolate of $F$. hepatica, even if cattle-derived miracidia from central France showed an increased infectivity towards snails from several years (Dreyfuss et al. 2007).

In conclusion, even if the present study demonstrates that allopatric L. neotropica and $L$. v. ventricosa are better intermediate hosts for French miracidia of $F$. hepatica, sympatric infections of South American lymnaeids with Argentinean miracidia were the most productive for metacercariae. This last finding throws the role of allopatric snails for parasite production into question. In our opinion, the above-mentioned results can only be explained by the report of Coelho et al. (2009). According to these authors, the success of a snail infection for the production of cercariae depended on the geographic origin of snails and flukes used for experiments.

\section{References}

Abrous M, Rondelaud D, Dreyfuss G, Cabaret J (1999) Infection of Lymnaea truncatula and Lymnaea glabra by Fasciola hepatica and Paramphistomum daubneyi in farms of central France. Vet Res 30:113-118

Abrous M, Rondelaud D, Dreyfuss G (2000) A field study of natural infections in three freshwater snails with Fasciola hepatica and/or Paramphistomum daubneyi in central France. J Helminthol 74:189-194
Bargues MD, Artigas P, Mera y Sierra RL, Pointier JP, Mas-Coma S (2007) Characterisation of Lymnaea cubensis, $L$. viatrix and $L$. neotropica n. sp., the main vectors of Fasciola hepatica in Latin America, by analysis of their ribosomal and mitochondrial DNA. Ann Trop Med Parasitol 101:621-641

Belfaiza M, Moncef M, Rondelaud D (2005) Fasciola hepatica: an unusual case of adaptation to a Moroccan population of Galba truncatula. Parasitol Res 95:374-378

Boray JC (1966) Studies on the relative susceptibility of some lymnaeids to infection with Fasciola hepatica and F. gigantica and on the adaptation of Fasciola spp. Ann Trop Med Parasitol 60:114-124

Boray JC (1969) Experimental fascioliasis in Australia. Adv Parasitol 7:95-210

Coelho LHL, Lima WS, Guimaraes MP (2009) Sympatric and allopatric combinations of Lymnaea columella and Fasciola hepatica from southern and south-eastern Brazil. J Helminthol 83:285-288

Dreyfuss G, Vignoles P, Rondelaud D (2007) Fasciola hepatica: the infectivity of cattle-origin miracidia had increased over the past years in central France. Parasitol Res 101:1157-1160

Dreyfuss G, Vignoles P, Rondelaud D (2010) Omphiscola glabra (Gastropoda, Lymnaeidae): changes occurring in natural infections with Fasciola hepatica and Paramphistomum daubneyi when this snail species is introduced into new areas. Ann Limnol-Int J Limnol 46:191-197

Duffy T, Kleiman F, Pietrokovsky S, Issia L, Schijman AG, Wisnivesky-Colli C (2009) Real-time PCR strategy for rapid discrimination among main lymnaeid species from Argentina. Acta Trop 109:1-4

Gasnier N, Rondelaud D, Abrous M, Boulard C, Carreras F, Diez-Banos P, Cabaret J (2000) Allopatric combination of Fasciola hepatica and Lymnaea truncatula is more efficient than sympatric ones. Int $\mathbf{J}$ Parasitol 30:573-578

Goumghar MD, Dreyfuss G, Rondelaud D, Benlemlih M, Cabaret J (2001) More efficient allopatric combinations of Fasciola hepatica and Lymnaea truncatula due to modification of redial development? Parasitol Res 87:1016-1019

Greischar MA, Koskella B (2007) A synthesis of experimental work on parasite local adaptation. Ecol Lett 10:418-434

Hoeksema JD, Forde SF (2008) A meta-analysis of factors affecting local adaptation between interacting species. Am Nat 171:275-290

King KC, Jokela J, Lively CM (2011) Trematode parasites infect or die in snail hosts. Biol Lett 23:265-268

Lively CM, Dybdahl MF (2000) Parasite adaptation to locally common host genotypes. Nature 405:679-681

Mas-Coma S, Funatsu IR, Bargues MD (2001) Fasciola hepatica and lymnaeid snails occurring at very high altitude in South America. Parasitology 123:115-127

Mera y Sierra R, Artigas P, Cuervo P, Deis E, Sidoti L, Mas-Coma S, Bargues MD (2009) Fascioliasis transmission by Lymnaea neotropica confirmed by nuclear rDNA and mtDNA sequencing in Argentina. Vet Parasitol 166:73-79

Mostafa OM, El-Dafrawy SM (2011) Susceptibility of Biomphalaria spp. to infection with Schistosoma mansoni in sympatric and allopatric combinations with observations on the genetic variability between snails. Vet Parasitol 180:226-231

Muñoz-Antoli C, Marin A, Trelis M, Toledo R, Esteban JC (2010) Sympatric and allopatric infections of the planorbid snail Gyraulus chinensis with miracidia of Euparyphium albuferensis (Trematoda: Echinostomatidae). J Helminthol 84:420-424

Ollerenshaw CB (1971) Some observations on the epidemiology of fascioliasis in relation to the timing of molluscicide applications in the control of the disease. Vet Rec 88:152-164

Osnas EE, Lively CM (2011) Parasite dose, prevalence of infection and local adaptation in a host-parasite system. Parasitol Res 109:675-687

Pointier JP, Cazzaniga NJ, González-Salas C, Gutiérrez A, Arenas JA, Bargues MD, Mas-Coma S (2006) Anatomical studies of sibling 
species within neotropical lymnaeids, snail intermediate hosts of fascioliasis. Mem Inst Oswaldo Cruz 101:431-435

Prugnolle F, de Meeûs T, Pointier JP, Durand P, Rognon A, Théron A (2006) Geographical variations in infectivity and susceptibility in the host-parasite system Schistosoma mansoni/Biomphalaria glabrata: no evidence of local adaptation. Parasitology 133:313-319

Reynal JL (2001) Enquête épidémiologique sur les traitements appliqués contre la fasciolose et la paramphistomose bovine dans le Sud-ouest de la Corrèze. Pharm D Thesis, Limoges

Rondelaud D, Denève C, Belfaiza M, Mekroud A, Abrous M, Moncef M, Dreyfuss G (2004) Variability in the prevalences of infections and cercarial production in Galba truncatula raised on a high quality diet. Parasitol Res 92:242-245

Rondelaud D, Fousi M, Vignoles P, Moncef M, Dreyfuss G (2007) Optimization of metacercarial production for three digenean species by the use of Petri dishes for raising lettuce-fed Galba truncatula. Parasitol Res 100:861-865

Sanabria R, Mouzet R, Pankrác J, Djuikwo Teukeng FF, Courtioux B, Novobilský A, Höglund J, Rašný M, Vignoles P, Dreyfuss G, Rondelaud D, Romero J (2012) Lymnaea neotropica and Lymnaea viatrix, potential intermediate hosts for Fascioloides magna. $\mathrm{J}$ Helminthol in press 